\title{
DAB2IP wt Allele
}

National Cancer Institute

\section{Source}

National Cancer Institute. DAB2IP wt Allele. NCI Thesaurus. Code C107123.

Human DAB2IP wild-type allele is located within 9q33.1-q33.3 and is approximately 218 $\mathrm{kb}$ in length. This allele, which encodes disabled homolog 2-interacting protein, may be involved in tumor suppression. 